\title{
FAKTOR-FAKTOR YANG MEMPENGARUHI DISCLOSURE SERTA DAMPAKNYA TERHADAP COST OF EQUITY CAPITAL
}

\author{
Sri Hermuningsih \\ Fakultas Ekonomi \\ Universitas Sarjanawiyata Tamansiswa Yogyakarta \\ e-mail: hermun_feust@yahoo.co.id
}

\begin{abstract}
The purpose of this study was to analyze the disclosure impact on the cost of equity capital companies listed on the Indonesia Stock Exchange. The population in this study were categorized LQ45 companies and is listed on the Indonesia Stock Exchange and the financial statements have been audited since 2006-2010, the number of samples was 182 companies. The statistical method used to test the hypothesis is Structural Equation Modeling (SEM). The results showed that: (1) investment opportunity set has positive and significant impact on disclosure (2) size has positive and significant impact on disclosure disclosure and significant negative effect on the cost of equity capital.
\end{abstract}

Keywords: investment opportunity set, size, disclosure, cost of equity capital

\section{PENDAHULUAN}

Setiap perusahaan dalam menjalankan usahanya selalu memiliki harapan untuk tetap going concern. Konsep going concern tersebut menuntut perusahaan untuk menjalankan kegiatan bisnisnya secara berkelanjutan. Dalam menjalankan keberlanjutan tersebut diharapkan perusahaan akan tumbuh dari tahun ke tahun. Pertumbuhan perusahaan sangat diharapkan baik oleh kalangan internal maupun eksternal dari sebuah perusahaan. Perusahaan dengan pertumbuhan yang tinggi membutuhkan lebih banyak dana karena banyak kesempatan investasi yang akan mereka lakukan. Bagi perusahaan pertumbuhan tersebut diharapkan dapat meningkatkan investasi, sedangkan bagi investor dampak positif dari pertumbuhan perusahaan bagi investor adalah tingginya return atas investasi yang mereka tanamkan.

Pertumbuhan yang selalu meningkat serta bertambahnya nilai aset perusahaan diharapkan tercapai sesuai dengan peramalan perusahaan. Esensi pertumbuhan bagi suatu perusahaan adalah adanya kesempatan investasi yang dapat menghasilkan keuntungan (Chung dan Charoenwong 1991). Pertumbuhan perusahaan menurut Smith dan Watts (1992) dapat diproksikan dengan berbagai macam kombinasi nilai set kesempatan investasi. Menurut Gaver dan Gaver (1993), pilihanpilihan pertumbuhan (growth options) bagi perusahaan tidak dapat diobservasi. Karena sifatnya yang tidak dapat diobservasi, IOS memerlukan sebuah proksi (Hartono, 1999). Nilai IOS dapat dihitung dengan kombinasi berbagai jenis proksi yang mengimplikasikan nilai aktiva yaitu berupa nilai buku aktiva dan ekuitas.

Investment Opportunity Set yang selanjutnya disingkat IOS merupakan suatu kombinasi antara aktiva yang dimiliki (asset in place) dan pilihan investasi pada masa yang akan datang dengan net present value positif (Myers,1977). Menurut Gaver dan Gaver (1993) pilihan investasi masa yang akan datang tidak semata-mata hanya ditunjukkan adanya proyek-proyek yang didukung oleh kegiatan riset dan pengembangan saja, tetapi juga kemampuan perusahaan yang lebih dalam mengeksploitasi kesempatan mengambil 
keuntungan dibandingkan dengan perusahaan lain yang setara dalam suatu kelompok industrinya. Pilihan investasi pada masa yang datang terkait dengan tingkat pertumbuhan nya, sehingga pertumbuhan perusahaan diharapkan memberikan aspek yang positif bagi perusahaan seperti adanya kesempatan berinvestasi.

Kebijakan disclosure masing-masing perusahaan berbeda sesuai dengan tingkat kepentingannya. Rata-rata emiten di Bursa Efek Indonesia memenuhi kewajiban untuk menyampaikan laporan sesuai dengan aturan BAPEPAM mengenai mandatory disclosure, sedangkan untuk voluntary disclosure tergantung dari kebijakan perusahaan masing-masing. Investor menggunakan laporan keuangan dan berbagai informasi yang disampaikan oleh tiap-tiap emiten untuk mengetahui bagaimana sebenarnya pertumbuhan perusahaan tersebut. Hal ini terkait dengan kemungkinan adanya peluang pertumbuhan investasi perusahaan tersebut.

Penelitian-penelitian empirik yang menguji pengaruh IOS terhadap disclosure telah dilakukan oleh Cahan dan Hosan (1995) mengenai hubungan antara IOS dengan kebijakan disclosure. Penelitian tersebut dilakukan dengan melihat kondisi pasar modal di Malaysia, menemukan terdapat hubungan positif antara IOS dengan kebijakan disclosure. Hossain et al.(2000) menemukan bahwa IOS berpengaruh positif dan signifikan terhadap pengungkapan dan manajer luar. Subekti dan Indra (2000), menemukan IOS berpengaruh positif dan signifikan terhadap pengungkapan. Hossain et al.(2005) juga menemukan IOS berpengaruh secara positif dan signifikan terhadap tingkat pengungkapan sukarela. Akhtaruddin dan Hossain (2008), menemukan tingkat pertumbuhan yang tinggi meningkatkan pengungkapan sukarela dengan adanya kontrol dari kepemilikan pemegang saham luar.

Berdasarkan latar belakang penelìtian yang telah dilakukan di atas, maka dapat diidentifikasì beberapa masalah yaitu: 1) Apakah investment opportunity set berpengaruh terhadap disclosure pada perusahaan yang masuk kategori LQ45 dan terdaftar di Bursa Efek Indonesia? 2) Apakah size berpengaruh terhadap disclosure pada perusahaan yang masuk kategori LQ45 dan terdaftar di Bursa Efek Indonesia? 3) Apakah disclosure. Berpengaruh terhadap cost of equity capital pada perusahaan yang masuk kategori LQ45 dan terdaftar di Bursa Efek Indonesia?

\section{KAJIAN PUSTAKA DAN \\ PENGEMBAGAN HIPOTESIS}

Investment Opportunity Set dan disclosure

Pengaruh IOS terhadap disclosure ditinjau dari dua teori, yaitu teori agensi (agency theory) dan teori sinyal (signal theory). Menurut teori keagenan yang pertama kali dikemukakan oleh Jensen dan Meckling (1976), berawal dari adanya pemisahan dan pengendalian perusahaan yang berdampak pada munculnya konflik antara agen dan prinsipal. Hubungan keagenan merupakan hubungan antara satu orang atau lebih prinsipal dengan agen untuk melakukan tindakan atas nama prinsipal yang melibatkan pendelegasian kewenangan pengambilan keputusan kepada agen. Konflik kepentingan antara prinsipal dan agen menimbulkan biaya keagenan, yaitu berupa biaya pengawasan (monitoring cost), biaya penjaminan (bonding cost) dan kerugian residual (residual loss). Adanya konflik tersebut, akan mengakibatkan menurunnya nilai perusahaan. (Jensen dan Meckling, 1976).

Teori keagenan mengimplikasikan adanya informasi asimetri antara manajer sebagai agen dan pemegang saham sebagai prinsipal. Informasi asimetri muncul ketika manajer lebih mengetahui informasi internal dan prospek perusahaan di masa yang akan datang dibandingkan dengan pemegang saham dan pemilik lainnya. Jika dikaitkan dengan peningkatan nilai perusahaan, ketika terjadi informasi asimetri 
manajer dapat memberikan sinyal mengenai kondisi perusahaa kepada investor guna memaksimisasi nilai saham perusahaan. Sinyal yang diberikan dapat dilakukan melalui pengungkapan (disclosure). Laporan keuangan merupakan sarana pengkomunikasian informasi keuangan kepada pihak-pihak di luar perusahaan.

Menurut Smith \& Watts (1992) dan Gaver \& Gaver (1993), pengaruh informasi asimetri terhadap perusahaan-perusahaan non-tumbuh lebih besar dari perusahaan yang bertumbuh. Namun, peran pengungkapan untuk mengurangi kesenjangan informasi dan biaya kagenan tidak dapat diabaikan. Pengungkapan informasi ini pada kenyataannya didorong oleh keinginan manajemen untuk menangani potensi konflik antara perusahaan dan pemegang saham secara efisien. Secara khusus, manajer akan melibatkan kegiatan yang akan meminimalkan biaya keagenan dan dengan demikian memaksimalkan nilai perusahaan (Diamond \& Verrecchia, 1991).

Cahan and Hossain (1995), menemukan IOS berpengaruh positif dan signifikan terhadap pengungkapan. Disebutkan bahwa perusahaan yang mempunyai peluang pertumbuhan perusahaan yang tinggi, manajer termotivasi untuk memberikan informasi mengenai prospek masa depan perusahaan. Hossain et al. (2000) mengungkapkan bahwa IOS berpengaruh positif dan signifikan terhadap pengungkapan. Hossain et al., (2005) meneliti pengaruh IOS terhadap pengungkapan sukarela dengan pendekatan simultan pada perusahaan-perusahaan di New Zealand, mereka menemukan IOS berpengaruh secara positif dan signifikan terhadap tingkat pengungkapan sukarela. Akhtaruddin dan Hossian (2008), menunjukkan bahwa perusahaan dengan tingkat pertumbuhan keuntungan yang tinggi, semakin tinggi pula pengungkapan sukarela dengan adanya kontrol kepemilikan

Pada akhir tahun 70-an (1977) beberapa penulis mengembangkan model signaling untuk mengukur struktur modal perusahaan dengan berlandaskan masalah informasi asimetri antara manajer yang mempunyai informasi bagus dan investor luar yang tidak mempunyai informasi. Model ini disusun berdasarkan ide bahwa manajer yang memiliki informasi yang bagus tentang perusahaan akan berusaha menyampaikan informasi tersebut kepada investor luar agar harga saham perusahaan meningkat. Namun karena ada masalah informasi asimetri, manajer tidak bisa hanya mengumumkan informasi bagus tersebut karena bisa jadi manajer perusahaan lain juga mengumumkan hal yang sama sehingga membuat investor luar menjadi kurang percaya.

Teori sinyal menjelaskan bahwa manajemen memberikan signal untuk mengurangi informasi asimetri. Jika manajemen mempunyai lebih banyak informasi mengenai kinerja dan prospek perusahaan daripada pemegang saham, mereka bisa memberi signal yang baik ke pasar dalam rangka untuk meningkatkan harga saham. Dalam penelitian ini IOS dengan menggunakan enam proksi yaitu : rasio nilai pasar aktiva terhadap nilai bukunya (MTBA), rasio nilai pasar ekuitas terhadap nilai bukunya (MTBE), rasio harga saham terhadap laba per lembar saham (PE), rasio investasi terhadap penjualan (INVOS), rasio pengeluaran modal terhadap nilai buku total aktiva (CAPXA). Hartono (1999), Kallapur dan Trombley (1999) dan Kumalahadi (2004) mengukur IOS dengan menggunakan enam proksi tersebut. Rasio-rasio ini diharapkan mencerminkan kesempatan investasi yang dimiliki perusahaan, yaitu semakin tinggi rasio-rasio IOS, semakin tinggi peluang pertumbuhan perusahaan, karena rasiorasio IOS merupakan gambaran yang bagus untuk pertumbuhan perusahaan. Jika perusahaan mempunyai peluang pertumbuhan perusahaan yang bagus, maka manajemen akan memberikan signal melalui disclosure. 
Dari uraian tersebut dirumuskan hipotesis dalam penelitian ini adalah: $\mathrm{H}_{1}$ : Investment Opportunity Set berpengaruh positif terhadap disclosure

\section{Size dan Disclosure}

Size perusahaan merupakan variabel yang banyak digunakan untuk menjelaskan pengungkapan sosial yang dilakukan perusahaan dalam laporan tahunan yang dibuat. Secara umum perusahaan besar akan mengungkapkan informasi lebih banyak daripada perusahaan kecil. Hal ini karena perusahaan besar akan menghadapi risiko politis yang lebih besar dibanding perusahaan kecil. Secara teoritis perusahaan besar tidak akan lepas dari tekanan politis, yaitu tekanan untuk melakukan pertanggungjawaban sosial. Dengan mengungkapkan kepedulian pada lingkungan melalui pelaporan keuangan, maka perusahaan dalam jangka waktu panjang bisa terhindar dari biaya yang sangat besar akibat dari tuntutan masyarakat. Pada penelitian ini size (ukuran) perusahaan dinyatakan dengan jumlah tenaga kerja yang dimiliki oleh perusahaan. Pengukuran ini dilakukan untuk mengetahui bahwa semakin besar jumlah tenaga kerja yang dimiliki maka akan semakin besar pula tanggung jawab sosial yang harus diungkapkan.

Dari uraian tersebut dirumuskan hipotesis dalam penelitian ini adalah:

$\mathrm{H}_{2}$ : Size berpengaruh negatif terhadap Disclosure

\section{Disclosure dan Cost of Equity Capital}

Beberapa faktor yang mempengaruhi COEC, antara lain disclosure Botosan, (1997). ukuran perusahaan Andadi (2006), financial leverage (Madichah, 2005). Disclosure adalah salah satu variabel yang dapat mengurangi COEC. Pertama, disclosure menurunkan COEC dengan mengurangi informasi asimetri dan meningkatkan likuiditas saham Diamond dan Verrecchia (1991). Kedua, disclosure juga menurunkan
COEC dengan mengurangi risiko estimasi. Botosan (1995) meneliti dampak tingkat pengungkapan terhadap COEC. Ia menguji asosiasi tingkat pengungkapan dan COEC dengan meregresi estimasi COEC atas beta pasar, ukuran perusahaan dan tingkat pengungkapan. Hasil penelitiannya menunjukkan bahwa semakin besar tingkat pengungkapannya maka COEC semakin rendah.

Mardiyah (2002) menguji pengaruh informasi asimetri dan disclosure terhadap cost of capital. Hasil penelitian menunjukkan bahwa asimetri informasi rendah, maka dibutuhkan disclosure yang semakin andal agar menurunkan cof of capital. Mardiyah (2004), meneliti pengaruh pengungkapan sukarela dan likuiditas pasar terhadap hubungan antara informasi asimetrik dan COEC, menunjukkan bahwa semakin tinggi pengaruh pengungkapan sukarela semakin rendah hubungan antara informasi asimetrik dan COEC. Juniarti dkk (2005) menemukan bahwa kualitas pengungkapan yang tinggi akan menurunkan COEC. Hal ini menunjukkan bahwa dengan pengungkapan sukarela maka tuntutan investor terhadap kompensasi menurun. Adanya pengungkapan sukarela yang tinggi menyebabkan menurunkan bid-ask spread sehingga menurunkan COEC. Pengungkapan sukarela dalam laporan keuangan dapat dipakai sebagai proksi ketidakpastian tentang prospek perusahaan di masa mendatang, karena keberadaan pengungkapan sukarela dalam laporan keuangan memungkinkan investor mendapatkan informasi tambahan untuk menilai prospek laba perusahaan di masa mendatang secara akurat, sehingga ketidakpastian tentang prospek perusahaan di masa mendatang semakin berkurang dan dapat diminimalkan, akibatnya pengungkapan sukarela semakin tinggi, maka COEC semakin rendah.

Akhtaruddin dan Hossian (2008), menunjukkan bahwa pertumbuhan keuntungan perusahaan lebih tinggi, tingkat pengungkapan sukarela tinggi, maka biaya 
modal ekuitas akan turun. Sementara perusahaan dengan pertumbuhan yang rendah ditandai oleh pengawasan kepemilikan oleh dewan yang lebih rendah, pengungkapan sukarela juga rendah. Penelitian teoritis dan empiris yang menguji pengaruh pengungkapan sukarela terhadap COEC antara lain: Diamond dan Verrcchia (1991), Coles et al. (1995), dan Clarkson (1996), Botosan (1997), Blommfied dan Jefferey (2000), Leuz dan Verrecchia, (2005), Yang Li et al., (2009), Puspita (2009), hasil penelitian mereka menemukan bahwa kualitas pengungkapan yang tinggi akan menurunkan COEC.

Disclosure merupakan sebuah jembatan komunikasi antara manajer dan investor. Semua informasi yang dimiliki oleh manajemen akan disampaikan kepada investor. Namun, apabila ada informasi yang tidak di-disclosure oleh manajer kepada investor maka akan terjadi informasi asimetri antara manajer dan investor. Semakin tinggi disclosure maka semakin rendah informasi asimetri antara manajer dan investor. Apabila informasi asimetri rendah maka risiko investasi menurun dan sebaliknya, semakin tinggi informasi asimetri maka semakin tinggi pula risiko investasi. Investor yang logis akan meminta return (expected return) yang lebih besar bila risikonya tinggi. Return harapan (expected return) inilah yang disebut dengan COEC. Dari logika berpikir ini dapat di simpulkan bahwa semakin tinggi tingkat disclosure akan semakin rendah informasi asimetri dan semakin rendah pula risiko investasinya sehingga menurunkan COEC yang diproksikan dengan tingkat return yang diharapkan oleh investor.

Jadi, apakah disclosure ini berguna dalam mengurangi COEC menjadi empiris isu yang dapat diuji dengan menggunakan hipotesis berikut.

$\mathrm{H}_{3}$ : Disclosure berpengaruh negatif terhadap Cost of Equity Capital.

\section{METODE PENELITIAN Populasi dan Penentuan Sampel Penelitian}

Populasi dalam penelitian ini adalah seluruh perusahaan yang telah terdaftar di Bursa Efek Indonesia 2006-2010. Pemilihan sampel dengan menggunakan metode purposive sampling, yang diperoleh sampel sejumlah 182 perusahaan.

\section{Data dan Metode pengumpulan Data}

Data yang digunakan dalam penelitian ini adalah data sekunder, yaitu data yang diperoleh dari catatan atau laporan historis dari arsip yang dipublikasikan dan laporan keuangan yang berasal dari Indonesian Capital Market Directory (ICMD). Data-data yang diperlukan untuk penelitian ini antara lain: 1) Jenis perusahaan yang termasuk ke dalam perusahaan LQ45 yang terdaftar di BEI. 2) Laporan tahunan (annual report) tahun 2006 sampai dengan tahun 2010. 3) www.Dunialnvestasi.com dan database dari Pojok BEI UII Yogyakarta dan Pojok BEI Universitas Sarjanawiyata Tamansiswa Yogyakarta. 4) Indeks laporan keuangan masing-masing sampel yang diperoleh dari butir-butir kelengkapan laporan tahunan perusahaan yang dapat diperoleh dari BAPEPAM KEP134/BL/2006

\section{Variabel dan Pengukurannya Variabel tidak bebas}

(Dependent Variable). Variabel dependen adalah biaya modal ekuitas (Cost of Equity Capital). Estimasi cost of capital dilakukan dengan menggunakan pendekatan Capital Asset Pricing Model (CAPM) dengan rumus:

$\operatorname{COEC}_{i t}=R_{f t}+\beta_{i}\left(R_{m t}-R_{f t}\right)$

Keterangan:

$\mathrm{COEC}_{i t}=$ estimasi Cost of Equity Capital perusahaan i pada tahun $\mathrm{t}$

$R_{f t}=$ Return bebas risiko yang diproksi dengan tingkat bunga SBI 1 bulan 
$R_{m t}=$ Return pasar yang diperoleh dari IHSG pada hari $\mathrm{t}$ ditambah IHSG pada hari $\mathrm{t}-1$ dibagi IHSG pada hari $\mathrm{t}-1$

$\beta i=$ Risiko tidak sistematis untuk setiap saham perusahaan

\section{Variabel bebas (independent variable)}

Investment Opportunity Set (IOS). IOS merupakan sesuatu yang sesuatu yang unobservable, maka diperlukan proksiproksi yang dapat digunakan untuk menggantikan IOS. Proksi yang digunakan dalam penelitian ini adalah proksi sebagaimana yang digunakan oleh Kumalahadi (2004) dengan menggunakan 6 (enam) yaitu:

$$
\begin{aligned}
& \begin{array}{l}
\text { Marketto Book } \\
\text { Asset }(\text { MTBA })
\end{array}=\frac{\begin{array}{c}
\text { Nilai buku } \\
\text { hutang }
\end{array}+(\text { embar saham } \times \text { Harga })}{\text { (yang beredar } \times \text { saham })} \\
& \text { Jmlh Lembar saham Harga } \\
& \begin{array}{l}
\text { Marketto Book } \\
\text { Equity }(\text { MTBE })
\end{array}=\frac{\text { yang beredar }{ }_{\text {saham }}}{\text { Total ekuitas }} \\
& \underset{\text { Ratio }(P E R)}{\text { Price Earning }}=\frac{\text { Harga saham }}{\text { Laba per lembar saham }} \\
& \begin{array}{l}
\text { Investment to } \\
\text { Sales (INVOS) }
\end{array}=\frac{\text { Total Aktiva tetap berujud }}{\text { Penjualan bersih }} \\
& \underset{\text { Earning }(I O E)}{\text { Investment to }}=\frac{\text { Total Aktiva tetap berujud }}{\text { Laba bersih }} \\
& \begin{array}{l}
\text { Capital to Total } \\
\text { Asset (CAPXTA) }
\end{array}=\frac{\text { Derubahan Aktiva tetap }}{\text { Total nilai buku aktiva }}
\end{aligned}
$$

Size

Ukuran perusahaan didefinisikan sebagai besaran atau suatu skala yang menunjukkan suatu usaha. Size perusahaan merupakan variabel yang banyak digunakan untuk menjelaskan pengungkapan sosial yang dilakukan perusahaan dalam laporan tahunan yang dibuat. Secara umum perusahaan besar akan mengungkapkan informasi lebih banyak daripada perusahaan kecil. Hal ini karena perusahaan besar akan menghadapi risiko politis yang lebih besar dibanding perusahaan kecil. Size merupakan ukuran perusahaan, dengan rumus: Size $=$ Ln total assets

\section{Disclosure}

Menurut Undang-undang No. 8 tahun 1996 tentang pasar modal, perusahaan public wajib menyampaikan laporan keuangan secara berkala kepada Badan Pengawas Pasar Modal (Bapepam)

Berdasarkan keputusan Keputusan

Ketua BAPEPAM-LK Nomor: Kep 134/bl/2006 tentang kewajiban penyampaian laporan tahunan bagi emiten (Bapepam, 2006) atau perusahaan publik yang dituangkan pada Peraturan Nomor X.K.6 adalah: (1) Kewajiban penyampaian laporan tahunan bagi emiten atau perusahaan public (2) Bentuk dan isi laporan tahunan. Disclosure, menurut Meek et.al. (1995), pengukuran luas pengungkapan menggunakan indeks (disclosures index, DI ), diperoleh dengan:

$$
D I=\frac{\begin{array}{c}
\text { Jumlah item } \\
\text { Informasi yang } \\
\text { dipenuhi }
\end{array}}{\begin{array}{c}
\text { Jumlah total item } \\
\text { informasi yang } \\
\text { mungkin dipenuhi }
\end{array}}
$$

\section{Teknik Analisis Data}

Penelitian ini menggunakan path diagram untuk menguji persamaan regresi yang melibatkan beberapa variabel eksogen dan endogen sekaligus sehingga memungkinkan pengujian terhadap variabel intervening. Diagram Jalur merupakan pengembangan lebih lanjut dari analisis regresi, sehingga analisis regresi dapat dikatakan sebagai bentuk khusus dari analisis jalur (regression is special case of path analysis) Ghozali (2011). Pengolahan data dengan bantuan Amos Versi 18.00. 


\section{Uji normalitas data}

Uji normalitas data bertujuan untuk menguji apakah data sampel berdistribusi. Pada penelitian ini uji normalitas menggunakan kriteria critical ratio skeweness value sebesar $\pm 2,58$ pada tingkat signifikasi 0.01. Apabila Z-value lebih kecil dari nilai kritis, maka dapat maka dapat diduga bahwa data berdistribusi tidak normal (Ghozali, 2011: 226).

\section{Uji kriteria Goodness of Fit Model}

Uji Goodness of-fit Model adalah mengukur kesesuaian input observasi sesungguhnya dengan prediksi dari model yang diajukan. Goodness-of Fit Model untuk mengukur kesesuaian input observasi (matrik kovarian atau korelasi) dengan prediksi dari model yang diajukan. Dalam analisis ini digunakan beberapa ukuran Goodnessof-fit Model (Ghozali: 2011)

\section{ANALISIS DAN PEMBAHASAN Analisis Diskriptif}

Berdasarkan Tabel 1 dapat dijelaskan bahwa variabel MTBA memiliki rata-rata sebesar 1,7989 dengan standar deviasi sebesar 1,91889, MTBE memiliki rata-rata sebesar 1,9649 dengan standar deviasi sebesar 1,90192 INVOS memiliki rata-rata sebesar 1,0624 dengan standar deviasi sebesar 1,22829, PE memiliki rata-rata sebesar 20,0242 dengan standar deviasi sebesar 15,44261. IOE memiliki rata-rata sebesar 7,9349 dengan standar deviasi sebesar 9,67664. CAPXTA memiliki ratarata sebesar 0,9031dengan standar deviasi sebesar 0,26925. MDISCL memiliki ratarata sebesar 0,6642 dengan standar deviasi sebesar 0,05662. VDISC memiliki rata-rata sebesar 0,6940 dengan standar deviasi sebesar 0,04406. COEC memiliki rata-rata sebesar 0,2591 dengan standar deviasi sebesar 0,25164. SIZE memiliki rata-rata sebesar 20,7759 dengan standar deviasi sebesar 5,92873.

\section{Analisis Data}

Pengolahan data menggunakan program AMOS (Analysis of Moment Structures) version 18. Dengan beberapa tahapan sesuai Ghozali (2011) sebagai berikut.

\section{Pengujian normalitas}

Pengujian normalitas dilakukan dengan mengamati nilai Skewness data yang digunakan apakah terdapat nilai CR yang melebihi $\pm 2,58$ pada tingkat signifikansi 0,01 . Uji normalitas dilakukan dengan menggunakan kriteria Critical Ratio sebesar $\pm 2,58$ pada tingkat signifikansi 0,01 (Ghozali, 2011).

Tabel 1: Deskripsi Variabel yang Diteliti

\begin{tabular}{lccrrr}
\hline & $\mathrm{N}$ & Minimum & Maximum & Mean & Std. Deviation \\
\hline MTBA & 182 & 0,02 & 8,30 & 1,7989 & 1,91889 \\
MTBE & 182 & 0,01 & 8,92 & 1,9649 & 1,90192 \\
INVOS & 182 & 0,01 & 5,75 & 1,0624 & 1,22829 \\
PE & 182 & 2,00 & 79,20 & 20,0242 & 15,44261 \\
IOE & 182 & 0,03 & 37,31 & 7,9349 & 9,67664 \\
CAPXTA & 182 & 0,00 & 1,93 & 0,9031 & 0,26925 \\
MDISCL & 182 & 0,52 & 0,93 & 0,6642 & 0,05662 \\
VDISCL & 182 & 0,58 & 0,85 & 0,6940 & 0,04406 \\
COEC & 182 & 0,01 & 0,95 & 0,2591 & 0,25164 \\
SIZE & 182 & 7,52 & 31,10 & 20,7759 & 5,92873 \\
Valid N (listwise) & 182 & & & & \\
\hline Sur: Data dis & & & & &
\end{tabular}

Sumber: Data diolah 
Tabel 2: Hasil Pengujian Normalitas

\begin{tabular}{lrrrrrr}
\hline Variable & min & max & skew & c.r. & Kurtosis & c.r. \\
\hline SIZE & 7,520 & 31,100 &, 343 & 1,887 & $-1,085$ & $-2,988$ \\
COEC &, 010 &, 950 & 1,052 & 5,794 &, 053 &, 146 \\
VDISCL &, 580 &, 850 &, 290 & 1,597 & 4,028 & 11,093 \\
MDISCL &, 520 &, 930 & 1,243 & 6,845 & 5,149 & 14,178 \\
MTBE &, 010 & 8,920 & 1,345 & 7,408 & 1,601 & 4,410 \\
MTBA &, 020 & 8,300 & 1,712 & 9,431 & 2,130 & 5,865 \\
PE & 2,000 & 79,200 & 1,704 & 9,386 & 3,351 & 9,228 \\
INVOS &, 010 & 5,750 & 1,864 & 10,265 & 3,397 & 9,356 \\
Multivariate & & & & & 29,495 & 15,729 \\
\hline
\end{tabular}

Hasil uji Normalitas Multivariate masih menghasilkan data berdistribusi tidak Normal, dengan hasil uji normalitas data memberikan nilai Critical Ratio multivariate sebesar 15,729 lebih besar dari nilai Cut of Value $(2,58)$. Untuk itu perlu dilakukan Estimasi dengan prosedur Bootstrap. Adapun, hasil bootstrapping untuk model penelitian ini adalah sebagai berikut. 1) The model fit better in 465 bootstrap samples. 2) It fit about equally well in 0 bootstrap samples. 3) It fit worse or failed to fit in 35 bootstrap samples. 4) Testing the null hypothesis that the model is correct, Bollen-Stine bootstrap $p=0,072$.

Berdasarkan hasil bootstrapping terhadap model penelitian ini diperoleh nilai probabilitas sebesar 0,072 Hasil probabilitas Bollen-Stine bootstrap $=0,082$ (lebih besar daripada nilai probabilitas $=0,001$ ) . Apabila Hasil Bollen-Stine bootstrap $=0,082$ (lebih besar daripada nilai probabilitas = 0,001), maka model hasil bootstrap adalah masih konsisten. Dengan demikian, tidak normalnya data secara multivariate pada model penelitian ini adalah masih dapat ditoleransi.

\section{Analisis jalur setelah dilakukan uji normalitas}

Gambar 1 adalah Analisis Jalur setelah dilakukan uji normalitas.

\section{Pengujian kesesuaian model}

Sebelum menganalisa hipotesa yang diajukan, terlebih dahulu dilakukan pengujian kesesuaian model (goodness-of-fit model) dengan hasil sebagaimana tampak pada Tabel 3.

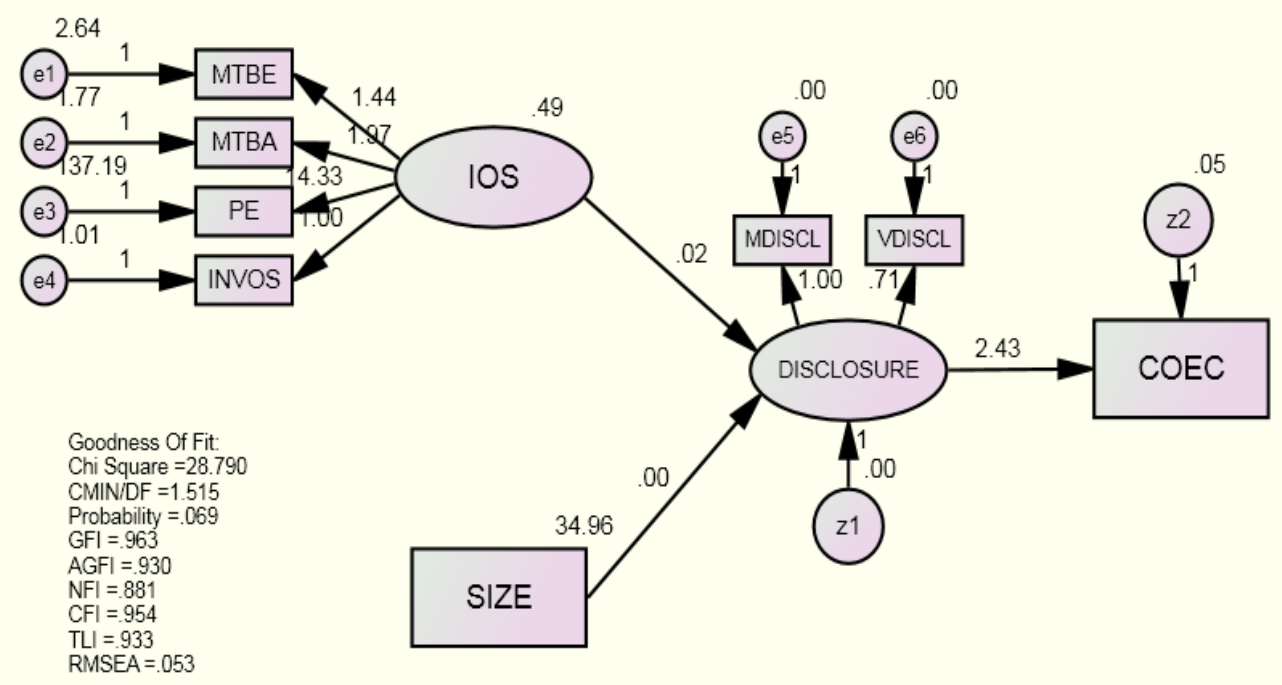

Gambar 1: Analisis Jalur 
Tabel 3: Pengukuran Tingkat Kesesuaian (goodness-of-fit)

\begin{tabular}{lccc}
\hline Goodness of Fit & Hasil Goodness Fit Of & Cut-off Value & Keterangan \\
\hline$\chi^{2}$-Chi-Square & 28,790 & Diharapkan Kecil & Baik \\
Probability & 0,066 & $\geq 0,05$ & Baik \\
CMIND/DF & 1,515 & $\leq 2$ & Baik \\
GFI & 0,963 & $\geq 0,90$ & Baik \\
AGFI & 0,930 & $\geq 0,90$ & Baik \\
TLI & $0,933$. & $\geq 0,90$ & Baik \\
NFI & 0,881 & $\geq 0,90$ & Cukup \\
CFI & 0,954 & $\geq 0,95$ & Baik \\
RMSEA & 0,053 & $\leq 0,08$ & Baik \\
\hline
\end{tabular}

Sumber: hasil perhitungan Goodness of Fit

\section{Analisis hasil pengujian hipotesis}

Investment Opportunity Set (IOS) terhadap Disclosure. Hipotesis 1 pada penelitian ini adalah IOS berpengaruh positif terhadap disclosure, yang artinya semakin tinggi IOS, maka semakin tinggi disclosure. Persamaan struktural ini merupakan hasil analisis data sebagai berikut.

$$
\begin{array}{ll}
\text { DISCL }= & 0,448 \text { IOS } \\
\mathrm{P} & (0,000) \\
\mathrm{CR} & (3,503)
\end{array}
$$

Dari hasil dari pengolahan data diketahui bahwa hasil pengujian terhadap hubungan kausalitas ini menemukan bukti untuk menerima hipotesis, karena memiliki nilai Critical Ratio (C.R.) 3,503 dengan nilai Probability $(\mathrm{P})$ sebesar 0,000 . Oleh karena nilai Critical Ratio $(\mathrm{CR}) \geq 2,58$ dan $\mathrm{P} \leq 0,05$, yang berarti suatu pengaruh yang signifikan. Dengan demikian hipotesis 1, yang menyatakan bahwa IOS berpengaruh positif terhadap disclosure terbukti.

Size terhadap Disclosure. Hipotesis 2, Size berpengaruh positif terhadap disclosure, yang artinya semakin tinggi Size, maka semakin tinggi disclosure. Persamaan struktural sebagai berikut.

$$
\begin{array}{lc}
\text { DISCL }= & 0,268 \text { Size } \\
\mathrm{P} & (0,004) \\
\mathrm{CR} & (2,885)
\end{array}
$$

Dari hasil dari pengolahan data diketahui bahwa hasil pengujian terhadap hubungan kausalitas ini menemukan bukti untuk menerima hipotesis, karena memiliki nilai Critical Ratio (C.R.) sebesar
2,885 dengan nilai Probability $(\mathrm{P})$ sebesar 0,001 . Oleh karena nilai Critical Ratio (CR) $\geq 2,58$ dan $\mathrm{P} \leq 0,05$, yang berarti suatu pengaruh yang signifikan. Dengan demikian hipotesis 2, yang menyatakan bahwa Size berpengaruh positif terhadap disclosure terbukti.

Disclosure terhadap Cost Of Equity Capital. Hipotesis 3, disclosure. Berpengaruh positif terhadap Cost Of Equity Capital, yang artinya semakin tinggi disclosure, maka semakin tinggi Cost of Equity Capital. Persamaan 37 struktural sebagai berikut.

$$
\begin{array}{ll}
\mathrm{P} & (0,000) \\
\mathrm{CR} & (3,784)
\end{array}
$$$$
\text { COEC }=0,003 \text { DISCL }
$$

Dari hasil dari pengolahan data diketahui bahwa hasil pengujian terhadap hubungan kausalitas ini menemukan bukti untuk menerima hipotesis, karena memiliki nilai Critical Ratio (C.R.) sebesar 3,784 dengan nilai Probability $(\mathrm{P})$ sebesar 0,001. Oleh karena nilai Critical Ratio (CR) $\geq 2,58$ dan $\mathrm{P} \leq 0,05$, yang berarti suatu pengaruh yang signifikan. Dengan demikian hipotesis 3, yang menyatakan bahwa disclosure berpengaruh positif terhadap COEC terbukti.

\section{PENUTUP Simpulan}

Dari hasil penelitian dapat disimpulkan bahwa, 1) Pada persamaan kesatu digunakan untuk menguji hipotesis satu menunjukkan bahwa IOS berpengaruh positif 
terhadap disclosure, yang artinya semakin tinggi IOS, maka semakin tinggi disclosure. Hal ini menunjukkan bahwa di Indonesia perusahaan mempunyai peluang investasi tinggi melakukan pengungkapan yang tinggi juga. Hossain et al.(2005), menyatakan bahwa IOS berpengaruh secara positif dan signifikan terhadap tingkat pengungkapan sukarela. 2) Pada persamaan kedua digunakan untuk menguji hipotesis dua menunjukkan bahwa size berpengaruh positif terhadap disclosure, yang artinya semakin tinggi size, maka semakin tinggi disclosure. 3) Pada persamaan ketiga digunakan untuk menguji hipotesis tiga menunjukkan bahwa disclosure berpengaruh positif terhadap cost of equity capital,yang artinya semakin tinggi disclosure, maka semakin tinggi cost of equity capital (Botosan, 1997) yaitu semakin besar tingkat pengungkapan, semakin rendah cost of equity capital. Atau sebaliknya laporan tahunan yang mempunyai indeks disclosure rendah akan berdampak semakin tinggi cost of equity capital. Artinya perusahaan masih belum mentaati seluruh ketentuan yang ada dalam Standar Akuntansi Keuangan dan peraturan dari Bapepam.

\section{Keterbatasan}

Dalam penelitian yang dilakukan ini masih kelemahan dan keterbatasan, yaitu adanya unsur subjektivitas dalam mengukur kualitas disclosure (pengungkapan) dalam laporan tahunan. Kualitas disclosure dinilai oleh peneliti berdasarkan interpretasi terhadap kandungan informasi laporan tahunan perusahaan sampel. Hal tersebut memungkinkan terjadinya perbedaan penilaian antar perusahaan karena kondisi subjektif peneliti.

\section{Implikasi}

Bagi penelitian berikutnya perlu mempertimbangkan penggunaan mean skor disclosure dalam pengukuran kualitas pengungkapan. Mean skor disclosure dapat diperoleh dengan cara melibatkan beberapa peneliti dalam menilai laporan tahunan. Penggunaan mean skor akan mengurangi masalah subjektivitas dalam penilaian kualitas disclosure yang hanya dilakukan oleh seorang peneliti, serta menambah sampel dan variabel penelitian sehingga hasilnya dapat untuk generalisasi.

\section{DAFTAR PUSTAKA}

Akhtaruddin, M. \& Hossian, M., (2008)," Investment Opportunity Set, Ownership Control and Voluntary Disclosures in Maylaysia", JOAAG, Vol. 3. No. 2

Andadi, Fachrial, D, (2006), Asimetri Information and Cost Of Equity Capital pada Perusahaan Go Public di Bursa Efek Jakarta (BEJ), Skripsi, Fakultas Ekonomi Universitas Brawijaya Malang, tidak dipublikasikan.

BAPEPAM, (2006), "Keputusan Ketua BAPEPAM-LK Nomor: Kep134/bl/2006", http://www.bapepam.go.id/old/hukum/peraturan/X/X.K.6.pdf

Bloomfield, R. J., \& Wilks, T. J. (2000), “Disclosure Effects in the Laboratory : Liquidity, Depth and the Cost of Capital", The Accounting Review, vol. 75 (1),hal. 13-41.

Botosan, Christine A, (1997), "Disclosure level and the Cost of Equity Capital", The Accounting Review, Vol 72, No 3, hal. 323-349. http://ssrn.com 2926

Cahan,S.F. dan M. Hossan, (1996), “The Investment Opportunity Set and Disclosure Policy Choice.," Asia Pasific Journal of Management,13 (1), pp. 65-85

Chung,Kee H., dan Charlie Charoenwong, (1991),"Investment Options, Assets in Place, and the Risk of Stocks," Financial Management, Autumn, pp. 21-33 
Clarkson, P., Guedes, J. And Thompson, R. (1996), “On The Diversification, Observability, and Measurement of Estimation Risk", Journal of Financial and Quantitative Analysis, vol. 31 (1), pp. 69-84.

Coles, J. L., Loewenstein, U. \& Suay, J. (1995), “On Equilibrium Pricing under Parameter Uncertaintiy", Journal of Financial and Quantitative Analysis, vol.30 (3), pp. 347-364.

Diamond dan Robert E. Verrcchia, (1991), "Disclosure. Liquidity ad The Cost Of Capital", Journal of Finance, Volume : 46.No 4, pp. 1325-59

Gaver J. Jennifer., dan Keneth M.Gaver. (1993), “Additional Evidence on the Association between the Investment Opportunity Set and Corporate Financing, Deviden, and Compensation Policies", Financial Management, 24, pp. 19-32.

Ghozali, Imam, (2011), Model Persamaan Struktural Konsep dan Aplikasi Dengan Proram AMOS 19.0., Badan Penerbit UNDIP Semarang

Hartono, Jogiyanto. (1999), "Agency Cost Explanation for Dividen Payment." Working Paper, Universitas Gadjah Mada

Hossain Mahmud, Kamran Ahmed, Jayne M. Godfrey, (2005), “Investment Opportunity Set and Voluntary Disclosure of Prospective Information: A Simultaneous Equations Approach", Journal of Business Finance E Accounting, Volume 32, Issue 56, pp. 871-907

Hossain Mahmud, Steven F. Cahan, Michael B. Adams , (2000), “The Investment Opportunity Set and the Voluntary Use of Outside Directors: New Zealand Evidence" , Accounting and Business Research, Vol. 30, No. 4, pp. 263-273,

Jensen, Michael C., dan William H. Meckling, (1976), “Theory of the Firm: Managerial Behavior, Agency Costs and Ownership Structure", Journal of Financial Economics, 3/4, pp. $305-360$.

Juniarti dan Frency Yunita, (2003), “Pengaruh Tingkat Disclosure Terhadap Biaya Ekuitas", Jurnal Akuntansi Petra, Vol 5, No 2

Kallapur, Sanjay dan Mark A Trombley,(1999),"The Association Between Investment Opportunity Set Proxies and Realized Growth," Journal of Bussiness Finance $\mathcal{E}$ Accounting, 26, April/May, pp. 505-519

Kumalahadi, (2004), Pengaruh Pemoderasi Aliran Kas Kejutan terhadap Hubungan Antara Set Kesempatan Investasi dan Reaksi Pasar, Disertasi, Program Pasca Sarjana UGM, tidak dipublikasikan.

Leuz, C., \& Robert E. Verrecchia. (2005), "The Economic Consequences of Increased Disclosure", Journal of Accounting Research, vol. 38, pp. 91-124.

Madichah, (2005), Pengaruh Earning Per Share (EPS), Dividen Per Share (DPS) Dan Financial Leverage (FL) terhadap Harga Saham Perusahaan Manufaktur di Bursa Efek Jakarta Periode 2000-2002, Skripsi, Fakultas ilmu sosial, Universitas Negeri Semarang, tidak dipublikasikan.

Mardiyah, Aida Ainul, (2002), "Pengaruh Informasi Asimetri dan Disclosure terhadap Cost of Capital", Jurnal Riset Akuntansi Indonesia, Vol. 5 No. 2, Mei, hal. 229-256. 
Meek, G. K., C.B. Roberts and S.J. Gray, (1995), “Factors influencing voluntary annual report disclosures in U.S., U.K. and continental European multinational corporations", Journal of International Business Studies, 26(3), pp. 555-72.

Myers, S. (1977), "Determinants of Corporate Borrowing", Journal Financial Economics, 5, pp. 147-175.

Puspita , Bahari Sandra, (2009), Pengaruh Tingkat Pengungkapan Informasi Terhadap Biaya Modal Ekuitas Pada Perusahaan Go Public Yang terdaftar di Bus Efek Indonesia, Skripsi, Fakultas Ekonomi Universtas Airlangga Surabaya, tidak dipublikasikan.

Smith, C. W. Jr., Watts, R. L., (1992)."The Investment Opportunity Set and Corporate Financing, Dividend and Compensation Policies". Journal of Financial Economics, 32, pp. 263- 292

Subekti, Imam dan Indra W. Kusuma, (2000), “Assosiasi Antara Set Kesempatan Investasi dengan Kebijakan Pendanaan dan Dividen Perusahaan, Serta Implikasinya Pada Perubahan Harga Saham", SNA, IV, IAI, hal. 820-845

Yang Li, Donald Stokes, Stephen Taylor, Leon Wong, (2009), “Audit Quality, Earning Quality and the Cost Of Equity Capital“.www.afaanz.org. 